\title{
Allelopathic Effect of Black Mustard Tissues and Root EXUdATES ON SOME CROPS ANd WeEd ${ }^{1}$
}

\author{
Efeito Alelopático de Tecidos de Mostarda-Preta e Exsudatos da Raiz de Algumas Culturas e \\ Plantas Daninhas
}

\begin{abstract}
AL-SHERIF, E..$^{2,4}$, HEGAZY, A.K. ${ }^{3}$, GOMAA, N.H. ${ }^{4}$, and HASSAN, M.O. ${ }^{4}$
ABSTRACT - Laboratory and greenhouse experiments were conducted to evaluate the phytotoxic effect of black mustard extracts and root exudates on two crops: Trifolium alexandrinum and Triticum aestivum, and two weeds: Phalaris paradoxa and Sisymbrium irio. The seeds were treated with aqueous and ethanolic extracts and chloroform for eight days, or subjected to root exudates of just harvested mustard in a greenhouse for five weeks. High-performance liquid chromatography (HPLC) was used to quantify phytotoxins from plant tissues. Seed germination of $P$. paradoxa was reduced with the lowest concentration of the different extracts. However, the aqueous extract at $4 \%$ completely curtailed the germination of all the target species. In general, plant extracts had a concentration-dependent reduction of seedling growth of the target species. However, the ethanolic extract, at the lowest concentration, has stimulated the shoot length of both $T$. alexandrinum and $T$. aestivum, and the root length of the former. Mustard root exudates inhibited emergence and growth of the target species throughout the experiment. Ferulic and syringic acids were the dominant allelochemicals found when HPLC was used.
\end{abstract}

Keywords: allelopathy, Brassica nigra, plant extracts, isothiocyanates (ITCs), phenolic acids.

RESUMO - Experimentos de laboratório e estufa foram realizados para avaliar o efeito fitotóxico dos extratos de mostarda-preta e exsudatos de raiz de duas culturas: Trifolium alexandrinum e Triticum aestivum, bem como de duas plantas daninhas: Phalaris paradoxa e Sisymbrium irio. As sementes foram tratadas com extratos aquosos, etanólicos e clorofórmio por oito dias, ou submetidas a exsudatos de raiz de mostarda recém-colhidaem estufa durante cinco semanas. A cromatografia liquida de alto desempenho (HPLC) foi usada para a quantificação de fitotoxinas a partir de tecidos de plantas. Sementes de $\boldsymbol{P}$. paradoxa apresentam germinação reduzida com a menor concentração dos diferentes extratos. No entanto, o extrato aquoso a $4 \%$ restringiu completamente a germinação de todas as espécies-alvo. Em geral, os extratos de plantas tiveram uma redução, dependendo da concentração do crescimento de mudas das espécies-alvo. No entanto, o extrato etanólico, na concentração mais baixa, tem estimulado o comprimento dos ramos de $\boldsymbol{T}$. alexandrinum e T. aestivum e o comprimento da raiz da primeira. Exsudatos de raiz de mostarda inibiram o surgimento e crescimento das espécies-alvo durante todo o experimento. Os ácidos ferúlico e siringico foram os aleloquimicos dominantes encontrados utilizando HPLC.

Palavras-chave: alelopatia, Brassica nigra, extratos vegetais, isotiocianatos (ITCs), ácidos fenólicos.

\section{INTRODUCTION}

Black mustard (Brassica nigra) is one of the common weeds worldwide. The allelopathic effect of Brassica spp. has been reported as the mechanism responsible for the inhibition of seed germination, for effects on coleoptile elongation and on radicle, for shoot and root development and for plant growth of many species (Tollsten \& Bergström, 1988;

Recebido para publicação em 30.3.2012 e aprovado em 26.10.2012.

2 Biology Department, Faculty of Sciences and Arts- Khulais, King AbdulAziz University, Saudi Arabia; ${ }^{3}$ Department of Botany, Faculty of Science, King Saud University, Saudi Arabia; ${ }^{4}$ Department of Botany, Faculty of Science, Beni Suef University, Egypt. Corresponding author, <address:emad_702001@yahoo.com> 
Choesin \& Boerner, 1991; Vaughn \& Boydston, 1997; Petersen et al., 2001; Turk \& Tawaha, 2002; Turk et al., 2005). Sinigrin is one of the major secondary metabolites produced by B. nigra (Mohn et al., 2007). Under enzymatic hydrolysis this compound liberates mainly the mustard oil (allyl isothiocyanates (ITCs)), which is supposed to be an important allelochemical of $B$. nigra (Olivier et al., 1999).

Natural herbicides derived from allelochemicals could be used to control several weeds, and it is theorized that they can minimize the risks to the environment. In addition, allelochemicals released in the environment can affect other plant species. For instance, glucosinolates may be involved on weed control (Fenwick et al., 1983). The biological activity is not usually attributed to glucosinolates directly, but rather to other compounds produced under enzymatic hydrolysis such as organic cyanides (CN), oxazolidinethiones (OZT), ionic thiocyanate ( $\mathrm{SCN}-$ ), and isothiocyanates, ITC, (Bangarwa et al., 2011). Myrosinase is responsible for such hydrolysis and remains stable within the dry plant tissues till hydrolysis, e.g. by soaking the dry plant material in water (Mohn et al., 2007). However, it may be difficult to determine the definite role of glucosinolate degradation products in biological activity. Moreover the assessment is complicated by the potential participation of other unidentified water soluble compounds (Choesin \& Boerner, 1991; Brown \& Morra, 1996). Therefore, it is necessary to know whether other phenolic compounds are participating in its allelopathic mechanism or not.

The objective of this study is to evaluate the allelopathic potential of $B$. nigra by using different extracts from the whole plant and from root exudates of this weed on seed germination and plant growth of two crops and two weeds.

\section{MATERIALS AND METHODS}

\section{Plant materials}

Black mustard plants, at the flowering stage (winter 2010), were collected from various farms located in Beni Suef Governorate, Egypt.
They were left in open areas to be air dried and grinded into finely divided parts. The seeds of the most important cultivated crops, Trifolium alexandrinum (Egyptian clover) and Triticum aestivum (wheat), were obtained from the Agricultural Research Center (ARC) in Giza. Ripe seeds of both black mustard and two weeds; Phalaris paradoxa (hood canary grass) and Sisymbrium irio (London rocket), were collected from farms at the Beni Suef Governorate region.

\section{Preparation of extracts}

Aqueous extract was obtained by mixing different amounts of Brassica powder $(10,20,30$ and $40 \mathrm{gm})$ soaked in distilled water (1 L) for $24 \mathrm{hrs}$ at $25{ }^{\circ} \mathrm{C}$ with mechanized shaking. The concentrations studied consisted of $1,2,3$ and $4 \%(\mathrm{w} / \mathrm{v})$. Filtration was carried out through a double layer filter paper (Whatman N.1). Distilled water was used as control.

Ethanol extract was obtained with the use of $150 \mathrm{~g}$ of finely divided residue of black mustard soaked in $2.5 \mathrm{~L}$ ethanol for 3 days. Afterwards, the solution filtrated three times in a Buchner funnel lined with a double layer of filter paper (Whatman N.1), and later centrifugation at $15.000 \mathrm{rpm}$ for 15 minutes to remove fine plant debris. The extract was transferred into a rotary evaporator under vacuum at $50{ }^{\circ} \mathrm{C}$ to remove the solvent. The concentrated extract was then transferred into a $50 \mathrm{ml}$ glass beaker to be completely dry. The removal of yield after solvent was $3.2 \mathrm{~g}$ of crude extract. The crude extract was dissolve din DMSO (Dimethyl sulfoxide) giving to the final concentration $60.000 \mathrm{ppm}$ at controlled pH 7, using $10^{-2} \mathrm{M}$ 2-[N morpholino] of ethanesuphonic acid (MES) and adding $1 \mathrm{M} \mathrm{NaOH}$ of solution. From the stock solution, the test concentrations were prepared as follows: 300, 600, 900 and $1.200 \mathrm{ppm}$. Buffered $1 \%$ aqueous solution of DMSO was used as control.

Chloroform extract was obtained through the same procedures described in the ethanolic extract. But the recovery after solvent removal was $2.3 \mathrm{~g}$ of crude extract. The same concentrations mentioned above were prepared. 


\section{Bioassay}

According to the different sizes for used seeds, twenty five seeds of Trifolium alexandrinum and Phalaris paradoxa, fifteen seeds of Triticum aestivum, and fifty seeds of Sisymbrium irio were sterilized with sodium hypochlorit $(5.25 \mathrm{w} / \mathrm{v})$ solution and placed on every Petri dish (9 $\mathrm{cm}$ diameter) lined with a filter paper. The treatments were arranged with four replicates receiving $10 \mathrm{~mL}$ of extract and placed in a slightly dark room with temperature ranging from 17 to $25^{\circ} \mathrm{C}$ for 8 days. Germination percentage was monitored daily to obtain the germination rate. After the experiment period, plumule and radicle lengths as well as germination percentage were recorded. Radicle to plumule ratio $(\mathrm{r} / \mathrm{s})$ parameter was used to estimate the effect of extract on either radicle or plumule lengths.

\section{Effect of root exudates}

Five seeds of Brassica nigra were sown at $1 \mathrm{~cm}$ depth in each test pot containing welldrained silty clay loam soil with $\mathrm{pH}$ 7.5. Control pots were kept without Brassica seeds but watered regularly in the same time with test pots. After emergence, two healthy Brassica seedlings were left in each test pot. Twenty seeds of each test species were sown in each pot at $1 \mathrm{~cm}$ depth after thirty days from Brassica emergence. Four replicates were used for each treatment. Plants were harvested after 35 days. At harvest, whole pot was gently inverted and each individual plant was separated carefully from soil with the help of pressured tap water. Each individual plant was then divided into root, stem and leaves to measure the root size, shoot height, and leaf area. Leaf areas were indirectly measured by weighing their tracings on a high quality paper and comparing them with a paper of known area and weight. These organs were oven dried at $70{ }^{\circ} \mathrm{C}$ till obtaining constant weight. Dry mass was recorded for the total individual as a total dry mass.

\section{Identification and quantification of allelopathic compounds}

The residue of Brassica nigra was extracted with water in a glass soxlet for $8 \mathrm{hrs}$. Then, the crude materials were dissolved in methanol, acidified with dilute phosphoric acid to $\mathrm{pH} 2.5$, and then partitioned two times with an equal volume of diethyl ether. The combined diethyl ether layers were evaporated and the resultant residue was dissolved in HPLC grade $\mathrm{MeOH}$ to give $1.000 \mathrm{ppm} .20 \mu 1$ was injected into the HPLC system. Identification of the phenolic compounds in the sample was determined by comparing the retention times of known peaks with that of the following pure standards: p-hydroxybenzoic, p-coumaric, caffeic, protocatechuic, chlorogenic, salicylic, vanillic, ferulic, shikimic, gallic, syringic, sinapinic, pyrogallic, and trans-cinnamic acids as well as scopoletin, coumarin and vanillin.

\section{Statistical analysis}

The experimental design was completely randomized with four replication sets. The results of all experiments were analyzed with one-way of ANOVA and the means were compared at the level $\mathrm{p}<0.05$. This analysis was carried out via the SPSS $\mathbb{R} / \mathrm{PC}$ computer software package see. 11.1. (2001).

\section{RESULTS AND DISCUSSION}

Both the extracts and root exudates of black mustard had inhibitory effects on germination and growth of the target species.

\section{Bioassay}

\section{Seed germination}

The seed germination was delayed for water extract treatments at increasing concentration. At $4 \%$ of water extract, seed germination of all test species was completely inhibited. Among the target species, Phalaris paradoxa was the most sensitive species for all extracts, recording a significant reduction in germination at the lowest concentration and a complete inhibition at the highest concentration of all extracts (Figure 1). Moreover, the degree of inhibition was rapid comparing with the other species. Meanwhile, Egyptian clover and wheat were not affected by the 300 and $600 \mathrm{ppm}$ in both ethanol and chloroform extracts (Figure 1A, B). 

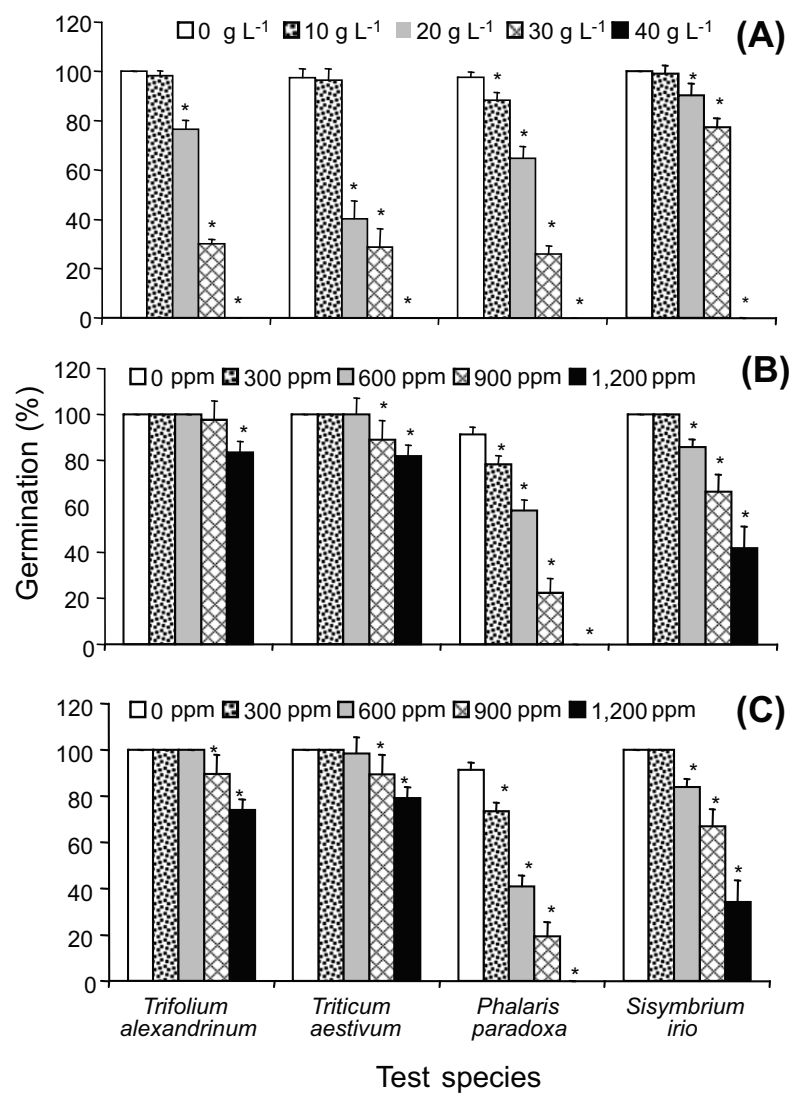

Figure 1 - Germination $\%$ of the studied species under the effect of different concentrations of the (A) aqueous extract, (B) ethanol extract and $(\mathrm{C})$ chloroform extract of $B$. nigra. Bars represent the standard deviation with four replicates.

\section{Seedling growth}

Although the degree of inhibition in either radicle or plumule lengths of the target species increased gradually with the increase of the different extracts concentrations, significant stimulations for shoot lengths of Egyptian clover and wheat ( 14 and $20 \%$, respectively) as well as root length of the former (14\%) were detected at $300 \mathrm{ppm}$ of ethanol extract. Meanwhile, there were recorded the most severely influenced radicle and plumule lengths by the $3 \%$ of water extract for Triticum aestivum (Figure 2A). The results showed that the radicle length was more sensitive to the different extracts compared to the plumule length; an obvious result due to the reduction in radicle/plumule ratio (Figure 3). Radicle/ plumule ratio of Sisymbrium irio recorded the highest reduction at $3 \%$ of water extract, while that of Phalaris paradoxa was delayed at $1.200 \mathrm{ppm}$ with either ethanolic or chloroform extracts.

\section{Effect of root exudates}

No seedling emergence was observed for Sisymbrium irio. However the emergence of Trifolium alexandrinum, Triticum aestivum and Phalaris paradoxa, was delayed $(\mathrm{p}<0.05)$ by 40 , 25 and $27 \%$, respectively, when compared with control (Figure 4).

Root exudates of Brassica nigra inhibited $(p<0.05)$ both the root and the shoot lengths of all test species when compared with that of controls (Figure 5A, B). Plant mass of Trifolium alexandrinum, Triticum aestivum and Phalaris paradoxa decreased by about 74, 60 and 94\% respectively (Figure 5C). Likewise, the leaf areas of the above test species were reduced by 69,77 and $92 \%$, respectively (Figure $5 \mathrm{D})$.

\section{Identification of allelopathic compounds}

Six phenolic compounds were identified in water extract of plant tissues. Among the compounds identified in the whole plant extract, ferulic, syringic, and affeic acids were the major phenolics produced, with mass production of 124,93 , and $58 \mu \mathrm{g} \mathrm{g}^{-1}$ of dry weight, respectively. $\mathrm{P}$-coumaric and protocatechuic acids, and vanillin (aldehyde) recorded the minor amounts, 18,39 , and $12 \mu \mathrm{g} \mathrm{g}^{-1}$ of dry mass, respectively (Table 1 and Figure 6).

The results showed that water extract of finely divided Brassica tissues greatly inhibited germination and seedling growth of the target species. Furthermore, the toxicity of the released compounds is species (target) dependant. This finding is in good agreement with the results of Mason-Sedun et al. (1986), where water extracts of $B$. nigra were mostly toxic to wheat comparing with the other test species. In addition, similar germination inhibition has been observed for lettuce, barnyardgrass and wheat when subjected to volatiles from $B$. nigra (Oleszek, 1987). Enzymatic hydrolysis of glucosinolates in Brassica tissues liberates various compounds (mainly ITC) that could inhibit seed germination (Brown \& Morra, 1996). ITC were 

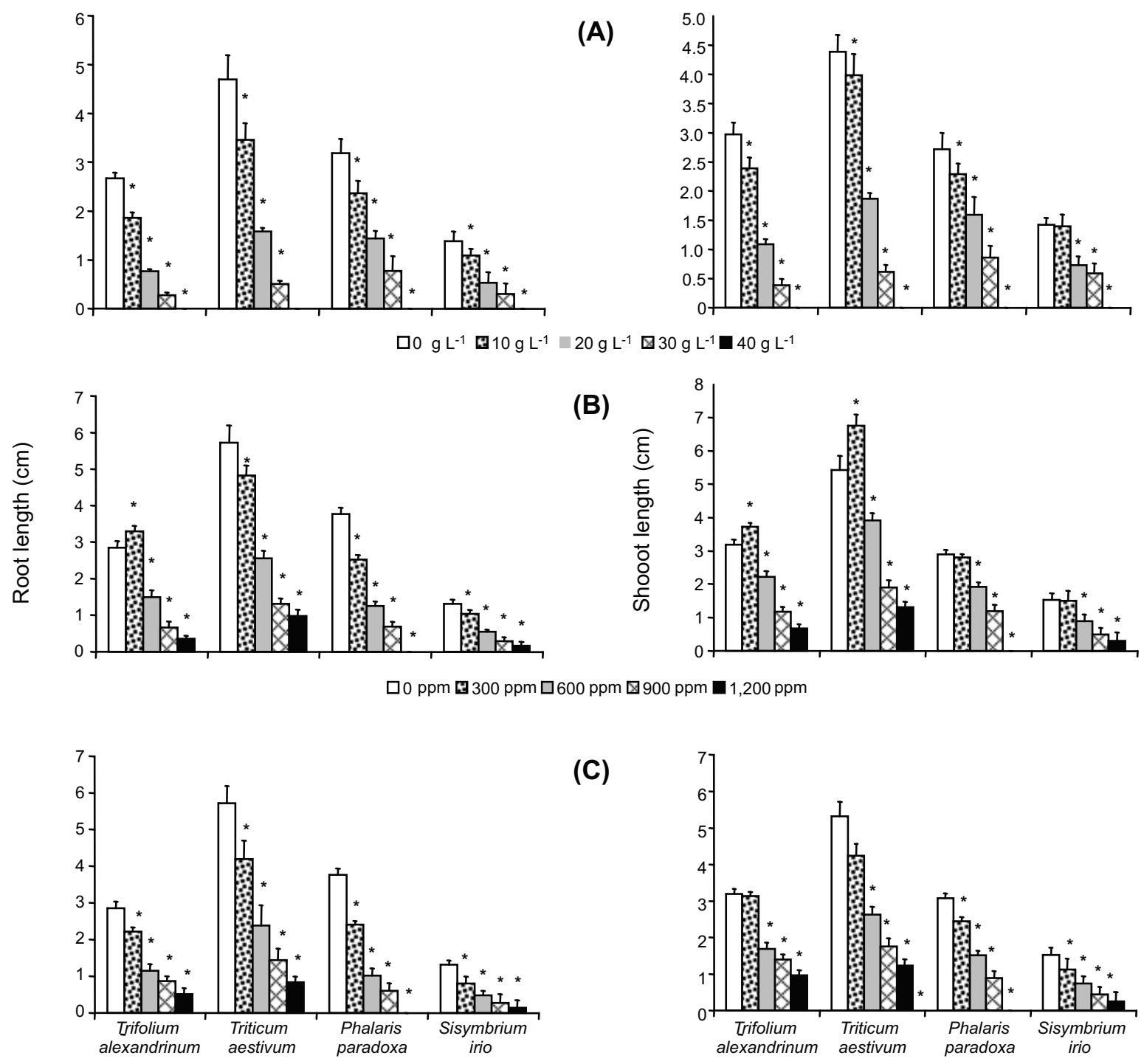

(C)

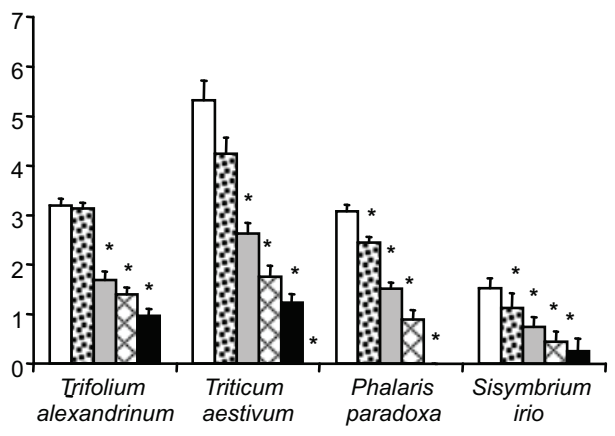

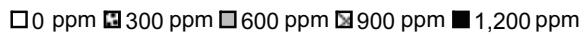

Test species

Figure 2 - Effect of (A) water extract, (B) ethanol extract and (C) chloroform extract of B. nigra on root length (cm) and shoot length $(\mathrm{cm})$. Bars represent the standard deviation.

suggested as biocides that may interact with proteins and amino acids, particularly with the sulfhydryl groups (Fenwick et al., 1983; Kawakishi \& Kaneko, 1985), amines (Kawakishi \& Kaneko, 1987) and disulfide bonds (Kawakishi \& Namiki, 1983) to form stable products. Thus, under higher concentrations of aqueous extracts of $B$. nigra, seed germination may be completely inhibited due to inactivation of the hydrolytic enzymes proceeding seed germination. This inhibition in both seed germination and seedling growth of the target species corroborates with germination (Turk et al., 2003) and growth (Turk et al., 2005) of alfalfa and radish. Furthermore, the results are in agreement with the literature in the fact that the inhibitory effect is dependent on the extract concentration (Turk et al. 2003, 2005; Ghareib et al., 2010; Hegab \& Ghareib, 2010). 

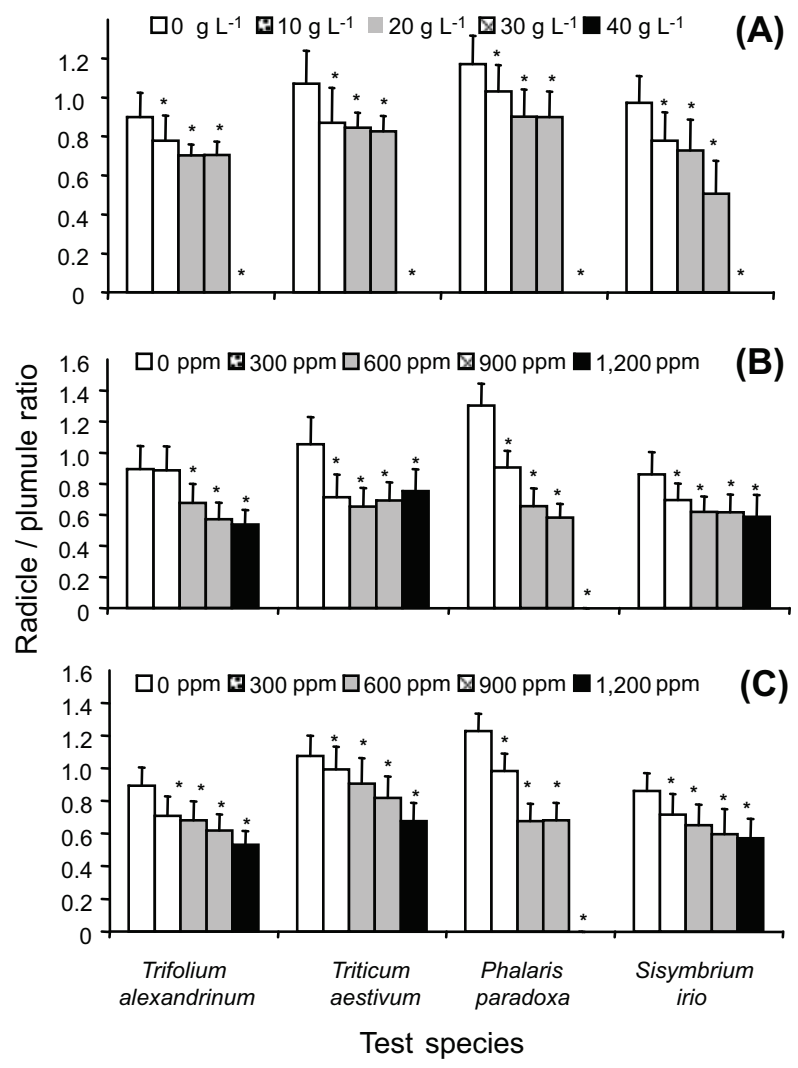

Figure 3 - Effect of (a) aqueous extract, (b) ethanol extract and (c) chloroform extract of $B$. nigra on radicle/plumule ratio. Bars represent the standard deviation with four replicates.

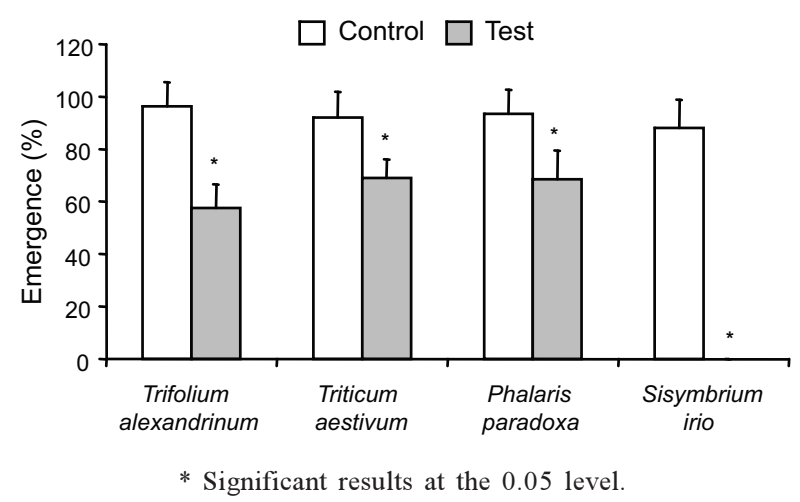

Figure 4 - Emergence percentage of the studied species under root exudates effect of Brassica nigra. Bars represent the standard deviation with four replicates.

The data showed that the type of solvent used in the extract was important. Both ethanol and chloroform extracts were less toxic to seed germination when compared with water extract, even under the highest concentrations. This could be attributed to a partial inactivation (denaturation) of myrosinase, the enzyme responsible for hydrolysis of glucosinolates to the most toxic products (Bennett et al., 2007). The fact that at low concentration the allelochemicals (see the ethanol extract) are growth stimulators is in agreement with other results from the literature (Einhellig, 2004; Ghareib et al., 2010; Hegab \& Ghareib, 2010).

It has been hypothesized that (Brown $\&$ Morra, 1996) the allelochemicals were not necessarily the hydrolysis products of glucosinolates, and there were other unidentified water soluble compounds participating in phytotoxicity. In our work, some phenolic compounds, recorded as allelochemicals, were detected in $B$. nigra throughout the HPLC analysis. Such identified phenolic compounds; ferulic, syringic, caffeic, $p$-coumaric, and protocatechuic acids, and vanillin (aldehyde) were recorded as allelopathic (Rice, 1984; Einhellig, 2004). The combined toxic action of such allelochemicals and ITCs is more effective. From literature reports, phenolic acids interfere with several enzymes and many physiological processes such as phytohormore activity, mineral uptake, photosynthesis, respiration and others (Einhellig, 1995). Thus, partial or complete germination inhibition may be attributed to inactivation of the enzymes responsible for germination by such allelochemicals. Also, complete germination inhibition at higher concentrations could result from death of embryos in seeds since such concentrations can be fatal. Reduction in growth may be attributed to water stress that reduces cell expansion or due to structural charges in membranes of the cells including alteration in membrane portions (Einhellig, 2004), or due to the suppression for cell division. Moreover, Einhellig (2004) stated that the early stage of seedling growth is very sensitive to phenolic acids. In this way, phytotoxicity of Brassica nigra may be strong due to the presence of some phenolic acids in addition to glucosinolates found in Brassica.

The results of this research may explain the field-observed long-term soil toxicity of B. nigra exudates (Tawaha \& Turk, 2003). 

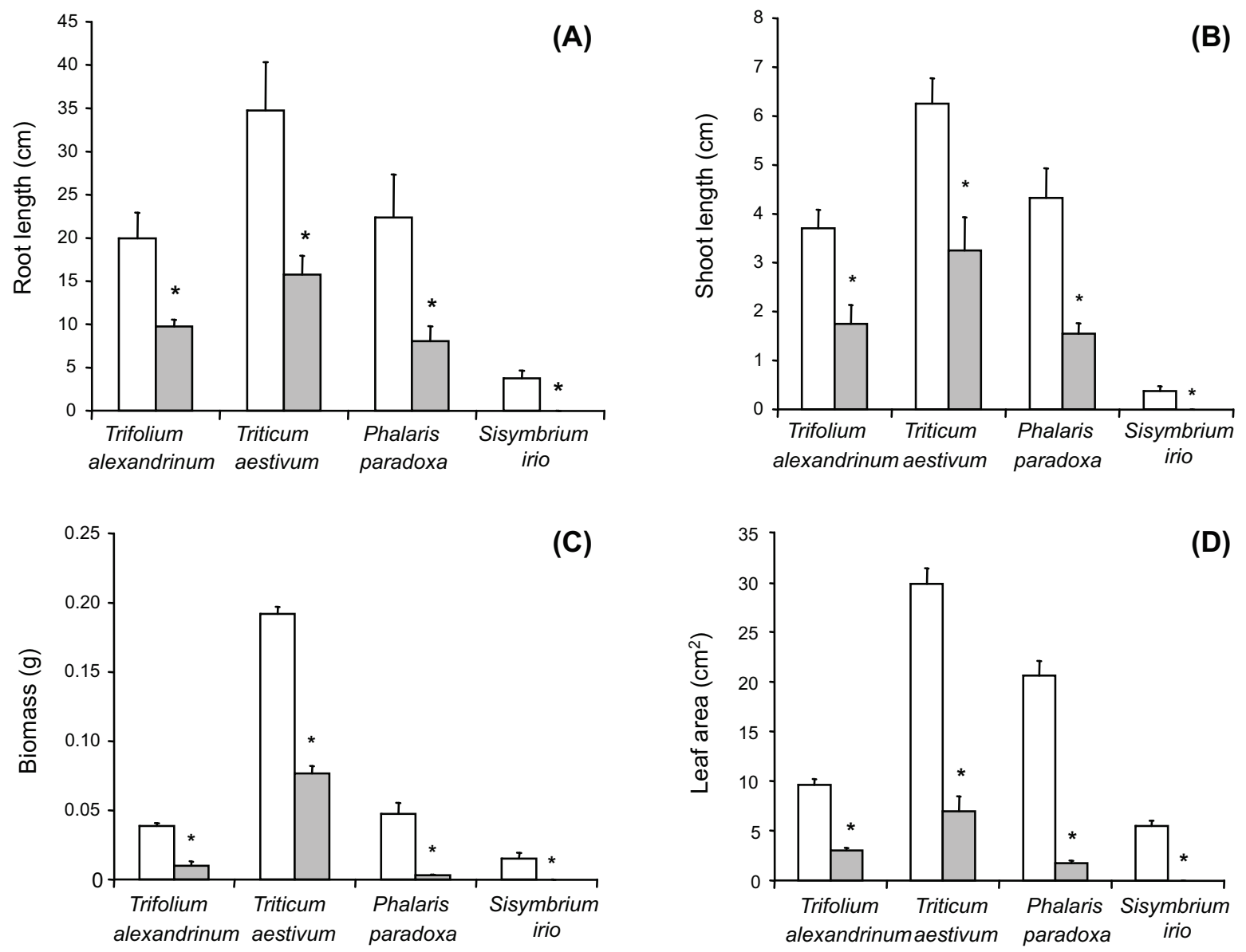

Control $\square$ Test

Test species

* Significant results at the 0.05 level.

Figure 5 - Root exudates effect of Brassica nigra on (A) root length, (B) shoot length, (C) total dry weight (biomass), and (D) leaf area $\left(\mathrm{cm}^{2}\right)$ of the study species. The bars represent the standard deviation with four replicates

Thus, in order for plant exudates to be persistent in the soil, it would be needed glucosinolate hydrolysis products to be released slowly and steadily from living plant parts (Haramoto \& Gallandt, 2004).

One possible explanation for stronger inhibitory effect of $B$. nigra extracts on roots, compared to the shoots of reagent plant species, is that roots were in direct contact with the extract and subsequently with inhibitory chemicals released from the donor plant (Qasem, 1995; Turk et al., 2005; Hassan $\&$ Ghareib, 2009).
Table 1 - Content of free phenolic compounds in Brassica nigra with their retention time ( $\mathrm{min}$.) and concentration ( $\mu \mathrm{g} \mathrm{g} \mathrm{g}^{-1}$ dry weight)

\begin{tabular}{|l|c|c|c|}
\hline \multirow{2}{*}{$\begin{array}{c}\text { Standard phenolic } \\
\text { compounds }\end{array}$} & \multicolumn{2}{|c|}{ Retention Time (min.) } & \multirow{2}{*}{$\begin{array}{c}\text { Concentration } \\
\left(\mu \mathrm{g} \mathrm{g}^{-1}\right)\end{array}$} \\
\cline { 2 - 3 } & Standard & Sample & 123.7 \\
\hline Ferulic acid & 24.680 & 24.698 & 18.22 \\
\hline Protocatechuic acid & 12.736 & 12.669 & 58.12 \\
\hline Caffeic acid & 18.016 & 18.101 & 93.5 \\
\hline Syringic acid & 18.379 & 18.400 & 38.68 \\
\hline$p$ - coumaric acid & 29.333 & 29.388 & 12.03 \\
\hline Vanillin & 22.411 & 22.30 & \\
\hline
\end{tabular}




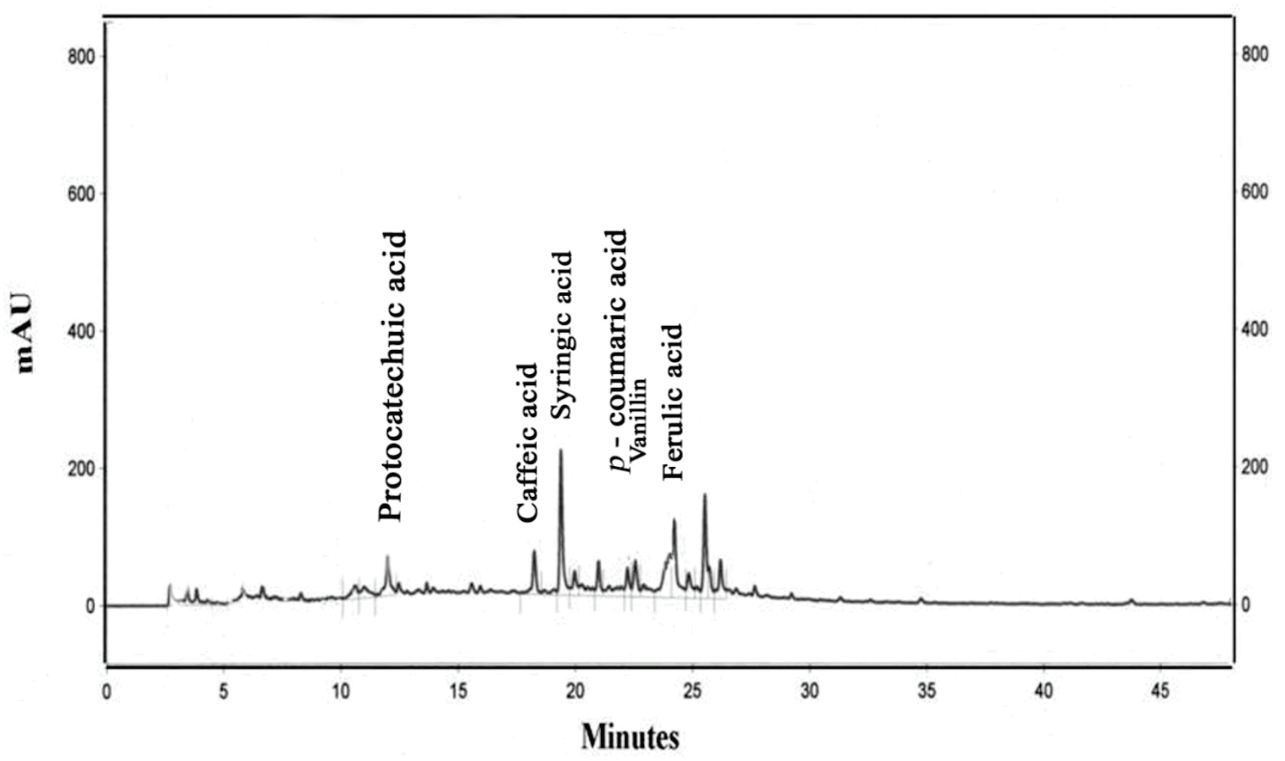

Figure 6 - HPLC chromatogram of free phenolic compounds detected in Brassica nigra.

The fact that both weeds species, Phalaris paradoxa and Sisymbrium irio, were more sensitive to the extracts from $B$. nigra than crop species suggests that black mustard allelochemicals may be used as bioherbicides. Alternatively, the capacity of the target species to tolerate or detoxify the allelochemicals should be considered (Schultz \& Wieland, 1999; Einhellig, 2004). The impact of allelochemicals on seed germination and seedling growth are acted from several aspects, which have been suggested to be on the hormone synthesis and usage, change cell division, elongation, microscopic structure, the membrane permeability and protein synthesis

In synthesis, this research has demonstrated that the toxicity of $B$. nigra extracts was caused by phenolic compounds. These chemicals are strong inhibitors of both seed germination and seedlings growth. At low concentration, the ethanol extract of black mustard had a stimulatory effect on the target species. The weed species Phalaris paradoxa and Sisymbrium irio are highly sensitive to the allelochemicals derived from $B$. nigra.

\section{LITERATURE CITED}

BANGARWA, S. K. et al. Glucosinolate and isothiocyanate production from brassicaceae cover crops in a plasticulture production system. Weed Sci., v. 59, n. 2, p. 247-254, 2011.
BENNET, R. N. et al. Identification and quantification of glucosinolates in sprouts derived from seeds of wild Eruca sativa L. (salad rocket) and Diplotaxis tenuifolia L. (wild rocket) from diverse geographical locations. J. Agric. Food Chem., v. 55, n. 1, p. 67-74, 2007.

BROWN, P. D.; MORRA, M. J. Hydrolysis products of glucosinolates in Brassica napus residues as inhibitors of seed germination. Plant Soil, v. 181, n. 2, p. 307-316, 1996.

CHOESIN, D. N.; BOERNER, R. E. J. Allyl isothiocyanate release and the allelopathic potential of Brassica napus (Brassicaceae). Am. J. Bot.p, v. 78, n. 8, p. 1083-1090, 1991.

EINHELLIG, F. A. Mechanisms of action of allelochemicals in allelopathy. Am. Chem. Soc. Symp. Ser., v. 582, n. 7, p. 96-116, 1995.

EINHELLIG, F. A. Mode of allelochemical action of phenolic compounds. In: MACIAS, F. A. et al. (Eds.). Allelopathy: chemistry and mode of action of allelochemicals. London: CRC Press, LLC, 2004. p. 217-238.

FENWICK, G. R. et al. Glucosinolates and their breakdown products in food and food plants. Crit. Rev. Food Sci.

Nutr.p, v. 18, n. 2, p. 123-301, 1983.

GHAREIB, H. R. et al. Antioxidative effects of acetone fraction and vanillic acid from Chenopodium murale on tomato plants. Weed Biol. Manag., v. 10, n. 1, p. 64-72, 2010.

HARAMOTO, E. R.; GALLANDT, E. R. Brassica cover cropping for weed management: A review. Renewable Agric. Food Syst., v. 19, n. 4, p. 187-198, 2004. 
HASSAN, S. M.; GHAREIB, H. R. Bioactivity of Ulva lactuca $\mathrm{L}$. acetone extract on germination and growth of lettuce and tomato plants. Afr. J. Biot., v. 8, n. 16, p. $3832-3838,2009$

HEGAB, M. M.; GHAREIB, H. R. Methanol extract potential of Field Bindweed (Convolvulus arvensis $\mathrm{L}$.) for wheat growth enhancement. Intern. J. Bot., v. 6, n. 1-9, p. 334-342, 2010.

WAKISHI, S.; KANEKO, T. Interaction of oxidized glutathione with allyl isothiocyanate. Phytochemistry, v. 24, n. 4 , p. 715-718, 1985.

KAWAKISHI, S.; KANEKO, T. Interaction of proteins with allyl isothiocyanate. J. Agric. Food Chem., v. 35, n. 1, p. 85-88, 1987.

KAWAKISHI, S.; NAMIKI, M. Oxidative scission of the disulfide bond of cystine and polypeptides by the action of allyl isothiocyanate. Agric. Food Chem., v. 47, n. 9, p. 2071-2076, 1983 .

MASON-SEDUN, W. et al. Differential phytotoxicity to wheat. Laboratory and field screening of species, Plant Soil, v. 93, n. 1 , p. $3-16,1986$.

MOHN, T. et al. Extraction and analysis of intact glucosinolates - A validated pressurized liquid extraction/ liquid chromatography - mass spectrometry protocol for Isatis tinctoria, and qualitative analysis of other cruciferous plants. J. Chrom., v. 1166, n. 1-2, p. 142-151, 2007.

OLESZEK, W. Allelopathic effects of volatiles from some cruciferous species on lettuce, barnyard grass and wheat growth. Plant Soil, v. 102, n. 2, p. 271-273, 1987.

OLIVIER, C. et al. Variation in Allyl isothiocyanate production within Brassica species and correlation with fungicidal activity. J. Chem. Ecol., v. 120, n. 12, 2687-2701, 1999.
PETERSEN, J. et al. Weed suppression by release of isothiocyanates from turnip - rape mulch. Agr. J., v. 93, n. 1, p. $37-43,2001$

QASEM, J. R. The allelopathic effect of three Amaranthus spp. (Pigweeds) on wheat (Triticum durum). Weed Res., v. 35, n. 1, p. $41-49,1995$.

RICE, E. L. Allelopathy. 2.ed. New York: Academic Press, 1984. p. 422.

SCHULTZ, M.; WIELAND, I. Variation in metabolism of BOA among species in various field communities biochemical evidence for co-evolutionary processes in plant communities. Chemoecology, v. 9, n. 1, p. 199-141, 1999

TAWAHA, A. M.; TURK, M. A. Allelopathic effects of black mustard (Brassica nigra) on germination and growth of wild barley (Hordeum spontaneum). J. Agric. Crop Sci. Res., v. 189, n. 5, p. 298-303, 2003

TOLLSTEN, L.; BERGSTROM, G. Headspace volatiles of whole plant and macerated plant parts of Brassica and Sinapis. Phytochemistry, v. 27, n. 12, p. 4013-4018, 1988.

TURK, M. A. et al. Inhibitory effects of aqueous extracts of black mustard on germination and growth of radish. Res. J.

Agric. Biol. Sci., v. 1, n. 3, p. 227-231, 2005.

TURK, M.A.; TAWAHA, A. M. Inhibitory Effects of aqueous extracts of black mustard on germination and growth of lentil. Pak. J. Agric., v. 1, n. 1, p. 28-29, 2002.

TURK, M. A.; et al. Inhibitory effects of aqueous extracts of black mustard on germination and growth of alfalfa. Weed

Biol. Manag., v. 3, n. 37, p. 40, 2003.

VAUGHN, S. F.; BOYDSTON, R. A. Volatile allelochemicals released by crucifer green manures. J. Chem. Ecol.p, v. 23, n. 9 , p. $2107-2116,1997$. 